\title{
Does genius border on insanity? \\ Part I: A relationship between creativity and the presence of psychopathological symptoms in bipolar disorder
}

\author{
Czy geniusz ociera się o szaleństwo? \\ Część I: Związek kreatywności z występowaniem objawów psychopatologicznych \\ w chorobie afektywnej dwubiegunowej.
}

\section{Olga Nowacka ${ }_{\mathrm{B}, \mathrm{D}, \mathrm{E}, \mathrm{F}, \text { Henryk Welcz }}^{2}$ A,B, Hanna Karakuła-Juchnowicz ${ }^{2,3}$ A,B, C,F}

${ }^{1}$ Student Research Group at the Department of Clinical Neuropsychiatry at the Chair of Psychiatry Medical University of Lublin

2 I Department of Psychiatry, Psychotherapy end Early Intervention, Medical University of Lublin

${ }^{3}$ Department of Clinical Neuropsychiatry, Medical University of Lublin

\begin{abstract}
The theory linking the development of mental disorders with the processes of human evolution assumes that these disorders may be the result of a side effect of natural and sexual selection processes. Creativity is one of the adaptive features associated with the increased incidence of psychopathological symptoms (as compared to the general population).

In this review paper, the definition of creativity has been characterized, and contemporary existing theories on its background, have been presented. Also, the paper describes the relationship between creativity and the presence of psychopathological symptoms. Special attention has been paid to the relationship between creativity and bipolar disorder.

The research results prove the existence of a correlation between a high level of creativity and a higher prevalence of psychopathological symptoms, particularly concerning the symptoms of bipolar disorder spectrum.
\end{abstract}

Keywords: creativity, bipolar disorder, psychopathology, affective symptoms, artistic talents

\section{Streszczenie}

Teoria wiążąca rozwój zaburzeń psychicznych z procesami ewolucji człowieka zakłada, że zaburzenia te mogą być skutkiem efektu ubocznego procesów doboru naturalnego i płciowego. Jedną z cech adaptacyjnych związanych ze zwiększoną w porównaniu do populacji ogólnej częstotliwością występowania objawów psychopatologicznych jest kreatywność.

W niniejszej pracy poglądowej scharakteryzowano definicję kreatywności oraz przedstawiono prezentowane współcześnie teorie dotyczące jej podłoża. Opisano także związek kreatywności z występowaniem objawów psychopatologicznych. Zwrócono szczególną uwagę na zależność między kreatywnością a chorobą afektywną dwubiegunową.

Wyniki badań dowodzą istnienia korelacji między wysokim poziomem kreatywności a częstszym występowaniem objawów psychopatologicznych, szczególnie dotyczących objawów ze spektrum choroby afektywnej dwubiegunowej.

Słowa kluczowe: kreatywność, choroba afektywna dwubiegunowa, psychopatologia, objawy afektywne, uzdolnienia artystyczne

\section{Introduction}

Darwin's theory of evolution assumes that natural and sexual selection not only affects the physical characteristics of individuals, but can also relate to their psychological behavior [1]. This could mean that certain mental disorders, such as anxiety, are the result of adaptive changes of the human species. Moreover, according to the concept of George Hamilton (1996), the theory of evolution can be compared to continuous competition of alleles of each gene [2]. In the gene pool the allele that remains, contributes more to the increase of its spread in subse- quent generations, even if for different individuals having this allele could mean the presence of certain adverse qualities, such as mental disorders [3]. The adaptive traits that increase the risk of psychopathological symptoms include creativity [4].

\section{Aim and method}

AIM

The aim of the study was to present the results of research on creativity and its relationship with the presence of psychopathological symptoms in bipolar disorder. 


\section{METHOD}

An analysis of the research works was made on the relationship between bipolar disorder and creativity using the database of Google Scholar, using the time frame 1950-2016 and key words: creativity, bipolar disorder, psychopathology, affective symptoms, artistic talents, natural selection.

For clarity of communication, this work is divided into several parts:

1. The origins of the concept and the definition of creativity.

2. Sources of creativity
2.1. Neurobiology of creativity
2.2. Creativity and natural selection
2.3. Creativity and sexual selection
2.4. Creativity and intelligence

3. The relationship between psychopathology and creativity

4. Creativity and bipolar disorder

4.1. Linking creativity types with a tendency to bipolar disorder

4.2. The dependence of bipolar disorder and the process of creating

4.3. Creativity and dopaminergic stimulation in bipolar disorder

5. Summary

\section{The origins of the concept and the definition of creativity}

In response to the need of adapting to changing conditions, both natural and social, there has been an extraordinary development of the human nervous system. But why on such a scale did the process appear only in representatives of our species? In Greek mythology, humanity received fire as a gift from Prometheus (J. Parandowski, 1992) [5]. It was a merciful gesture of god, who wanted to give man the opportunity to warm up and have protection. In fact, man by observing processes leading to the spontaneous appearance of fire, and having simple tools, finally learnt how to make it. A powerful advantage, which man thus gained, results from absent in other species, and exceptionally lively in humans - creativity. It is not surprising that the word creativity is derived from the concept of creation, (from the Latin "creatio" - creation ), which in ancient times functioned in human consciousness as the effect of divine intervention [6]. As described by Stein (1953), "creative thinking is born from a combination of newly existing materials or knowledge, which when added include brand new elements" [7]. According to Runco (2012), "Creativity requires the fulfillment of two criteria - originality/novelty and broadly understood effectiveness, efficiency of the generated in the creative process, creative products" [8]. Also, Rybakovsky (2006) accepts as the definition of creativity: "The ability to create new, socially useful or influential ideas" [9]. People easily adapt to the conditions in which they live, using the given them tools in an innovative way. Why, though, did the human race develop this feature?

\section{Sources of creativity}

To be considered creative work, it is required that its result is not only original but also to some extent socially useful [8]. Usability indicates that newly formed ideas or products are not a coincidence. This in turn supports the idea that creativity is associated with some higher mental processes: "When giving into the hands of the chimpanzee a paintbrush, we can expect over time that the chimpanzee will paint its new, previously unseen image. It will never be, however, a creative work "[8].

Below, there will be presented theories linking the rise of creativity in humans with particular neurochemical structures of our nervous system. Then attention will be paid to the link between the development of creativity with natural selection, as well as the ratio of the level of intelligence to creativity.

\subsection{Neurobiology of creativity}

Tests allowing for imaging the brain have contributed to the development of knowledge on the neurobiological grounds of creativity. As it turns out, no particular domination of any of the hemispheres, but close cooperation between them and the mesolimbic system enables its outstanding development (Mayseless et al., 2015) [10]. Rybakovsky (2006) considers the formulation of new ideas equally important in the process of creating, for which mainly frontal and temporal lobes are responsible, as well as the so-called creative impulse. It depends on the work of the mesolimbic dopamine pathway. The dopaminergic system is responsible for increasing motivation to take the creative process. It also increases the sensitivity to external stimuli. This increased activity of dopamine explains the lower than in the average individuals latent inhibition in people artistically talented [9].

\subsection{Creativity and natural selection}

However, explanation of neurochemical brain activity responsible for the process of creative thinking does not explain, distinguished even in humans universality of this feature, or its scope.

It is estimated that about 150,000 years ago, our ancestors developed all necessary anatomical features allowing them to develop creativity [11]. Archaeological works suggest, however, that real progress, occurred 
much later, about 30-40 thousand years ago. Probably this time gap was a period of natural selection. Endowed with creativity, people had better chances to adapt to the changing nature through the development of appropriate working methods and increasingly complex tools [11].

\subsection{Creativity and sexual selection}

The creator of the theory of evolution, Charles Darwin, saw outstanding creativity in the development of our species in sexual selection [12]. Research of Hasselton and Miller (2002) confirms that women in the fertile phase of the menstrual cycle are more likely to enter into a relationship with a partner of low economic status, endowed with artistic talent, than with a rich partner, but devoid of similar ability [13]. The works of Buss et al. [14] show that a sense of humor, which also has to do with creativity, is a strong asset in the selection of potential partners. So, would incredible creative fertility of artists such as Schuman, Goethe and Tchaikovsky have been a side effect of the pursuit of our species to incredible expansion and development? And maybe the efforts of individuals to ensure the continuity of their family line?

\subsection{Creativity and intelligence}

Certainly, a highly developed intelligence is not a prerequisite for the manifestation of artistic talent. It can be evidenced by the unique ability of people called 'idiot savants'. Many of these extraordinary people, often with IQ below 40 exhibit above-average artistic talent, especially musical and in the arts [15]. An example is the story of Leslie Lemke, who despite IQ below 58 points was able to perform by ear music of Tchaikovsky (Treffert, 1989) [16]. Research studies on idiot savants show significant correlation between a strong development of the right hemisphere relative to the left (e.g. as a result of defects or failures within the left hemisphere), and the disclosure of the above-average artistic capabilities (T. Brink, L., 1980) [17,18] . Creative people need not have extraordinary capabilities in science, but is it possible that extremely creative individuals can also be intellectually handicapped? Do ideally performed sonata or perfectly reproduced copy of the works of art testify to innovation and originality of thinking? There is a fine line between master reproduction and creation, requiring that creativity must be so clearly emphasized. Research by Barron (1981) shows that although a high level of intelligence does not equate with the presence of creativity, it is a necessary condition for its development [19].

\section{The relationship between psychopathology and creativity}

Based on the analysis of the biographies of many famous people - the relationship between creativity and propensity to mental illness seems to be close and obvious. Even the most famous ancient Greek philosopher Aristotle proclaimed that "there is no genius without a pinch of madness". In the words of the famous British poet Lord Byron: "We artists are all mad. We of the craft are all crazy. Some are affected by gaiety, others to melancholy, but all are more or less touched "(A. Sussman, 2007) [20]. Ironically, it seems likely that Byron suffered from bipolar disorder. Moreover, there were non-rare cases of mental illness in his family (Ahmed Hankir, 2011) [21]. Research conducted so far has confirmed the existence of a correlation between the level of creativity and individual mental disorders. Andreasen [4] reports that in first-degree relatives of known writers, the incidence of mental illness and creativity level is elevated. Jamison (1989) in his work confirms that $38 \%$ of the surveyed British writers and artists show affective disorders [22]. Ludwig (1994) in research studies of female writers indicates a direct relationship between creativity and the occurrence of symptoms of psychopathology [23]. These works also encouraged to further questions, among others, whether particular psychopathological symptoms affect an increase or decrease in the level of creativity or whether the individual stages of the diseases coincide with the reduction or suppression of creativity in patients (Gharidian et al., 2001) [24].

\section{Creativity and bipolar disorder}

The results of studies conducted so far indicate that the relationship between psychopathological symptoms and the level of creativity is most strongly visualized only in bipolar disorder [25]. Linking of bipolar disorder to creativity is exhibited both in detailed analyzes of biographies of prominent artists and in randomized clinical trials on creativity among people diagnosed with bipolar disorder. Akiskal and Akiskal (1988) in their research covering 750 patients showed that patients with type II and III bipolar disorder are characterized by increased artistic creativity in relation to the control group [26]. Research of Richards et al. (1988) shows that artists with bipolar disorder are characterized by a long artistic career in comparison with artists without a diagnosis of affective disorders. Both adults with cyclothymia and first-line relatives of people with bipolar disorder (but not patients themselves) have significantly higher scores in artistic creativity in comparison to the control group [27].

\subsection{Linking creativity varieties with a tendency to bipolar disorder}

Interestingly, the study by Sass (2001) indicates the existence of a significant relationship between the occurrence of bipolar disorder and creativity especially among artists [28]. Less distinct relationships are noticeable with 
creative people, e.g. in the fields of science (Simonton, 2001) [29]. Artists in fact are characterized by different type of creativity than e.g. engineers or mathematicians [30]. It is noted that to a large extent, in addition to creativity, artists are characterized by nonconformity, complexity of interests. They attribute great importance to intuition and independence [31]. This issue is developed by Sass (2001), by combining the correlation between bipolar disorder and creativity of artists with some specific personality predispositions such as emotionality, applying great importance to prevailing social hierarchy ("superiority felt in mania, sense of rejection in depression") [ 28]. Can we treat bipolar disorder as a side effect of extraordinary sensitivity motivating artists in their creative work? Nancy Andreasen (2008) notes that excessive sensitivity to surrounding stimuli might also lead artists to seek solutions to mitigate the severe mood swings [32]. This could explain the tendency of artists to alcohol abuse (Prisciandaro et al., 2011) [33], as well as accidental often made suicide attempts (Ludwig, 1997) [34].

\subsection{The dependence of bipolar disorder and the crea- tive process of creating}

Akiskal and Akiskal also note that high creativity applies to patients characterized mainly by mild disease [26]. Work of Gharidian et al., also draws attention to the link between high creativity values with only mild to moderate symptoms of psychopathology [24]. The highest artistic fertility of creativity of the British writer Virginia Woolf (18821941) suffering from bipolar disorder overlapped over time with episodes of illness characterized by mild mood swings. Severe episodes were, in turn, the stages of a clear decline in creativity. One can only presume that the experiences of these periods were the inspiration for the creation of new works. Struggles with relapse in 1941 led the outstanding artist to suicide [31]. Research works of Andreasen (2008) relate a period of recovery from depression with the utmost ingenuity of artists suffering from bipolar disorder. This ingenuity resulting, as researchers think, from deep experience of the period of the disease, results in an explosion of creativity in the hypomanic phase [32]. Greater creativity in hypomania than in mania has been confirmed by the results of work by Akiskal and Akiskal (1988). It was observed that the level of creativity in various episodes of the disease was distributed from the highest to the lowest: hypomania, mania, hypodepression, depression [26].

\subsection{Creativity and dopaminergic stimulation in bipolar disorder}

High rates of creativity are associated with increased transduction in terms of the dopaminergic system (Soeiro- de- Souza, 2011) [35]. These results were confirmed by analysis of the biography of the famous composer Robert Schumann (1810-1856). The episodes of mania resulted in deep damage to the joints of the right hand, connected with too intense playing the piano. However the hypomanic states in him were related with periods of insomnia and auditory musical hallucinations. After a few days of constant creative work, Schumann would fall slowly into a state of depression. Creativity would leave him, giving way to fatigue, suicidal thoughts, visual hallucinations and hopelessness. Finally, in 1854, after a failed suicide attempt, Schumann was placed in a psychiatric hospital, he died a year later (Kusz W., 2010), Ostwald P. (1985) [36,37]. The researchers interpreting a biography of the German writer - Johan Wolfgang Goethe reached very similar conclusions. A thorough analysis led to conclude that the writer suffered from bipolar disorder type II (R.M. Hadulla-Holm et al., 2010). As it turns out, depressive episodes gave the artist the inspiration and motivation to create even the famous "Faust." The hypomanic states allowed him to overcome the feeling of doubt, introduced into complacency, and thus helped to turn the mental concept in the finished work [38].

\section{Summary}

Struggling with mental illness of prominent artists such as Sylvia Plath, Ernest Hemingway, Vincent van Gogh or Emily Dickinson, make us ask the question whether genius borders on insanity. It would be banal and unjust to say that insanity defined as the occurrence of psychotic symptoms is synonymous with genius. As analysts of Goethe biography said, the writer throughout his life learned how to accept and alleviate his mood disorder. The artist each time anew overcame the states of anxiety, feelings of isolation and melancholy. However, this led him to mastery in the field of literature [38]. Great suffering, related often with symptoms of mental illness, which without doubt is involving the most famous artists, can be interpreted as a side effect of great creativity or as part of the hard way by which every artist is forced to walk alone.

\section{Wstęp}

Teoria ewolucji Darwina zakłada, że dobór naturalny i płciowy nie tylko wpływa na cechy fizyczne osobników, ale także może odnosić się do ich zachowań psy- chicznych [1]. Może oznaczać to, że pewne zaburzenia psychiczne, na przykład lękowe, są wynikiem zmian adaptacyjnych gatunku ludzkiego. Co więcej, według koncepcji George'a Hamiltona (1996), teorię ewolucji można po- 
równać do ciągłej konkurencji alleli poszczególnych genów [2]. W puli genów pozostaje ten allel, który bardziej przyczynia się do zwiększenia swojego rozprzestrzenienia w kolejnych pokoleniach, nawet jeżeli dla poszczególnych osobników posiadających ten allel wiązać by się to miało z występowaniem pewnych niekorzystnych dla niego cech, na przykład zaburzeń psychicznych [3]. Do cech adaptacyjnych zwiększających ryzyko występowania objawów psychopatologicznych jest zaliczana kreatywność [4].

\section{CEL I METODA}

Cel pracy:

Celem pracy było przedstawienie na podstawie przeglądu dostępnej literatury, wyników badań dotyczących kreatywności oraz jej związków z występowaniem objawów psychopatologicznych w chorobie afektywnej dwubiegunowej.

\section{Metoda:}

Dokonano analizy prac dotyczących powiązań między chorobą afektywną dwubiegunową a kreatywnością korzystając z baz danych Google Scholar, używając deskryptorów czasowych 1950-2016 i słów kluczy: kreatywność, choroba afektywna dwubiegunowa, psychopatologia, objawy afektywne, uzdolnienia artystyczne, dobór naturalny.

Celem przejrzystości przekazu niniejsza praca została podzielona na poszczególne części:

1. Geneza pojęcia oraz definicja kreatywności.

2. Źródła kreatywności

2.1. Neurobiologiczne podłoże kreatywności

2.2. Kreatywność a dobór naturalny

2.3. Kreatywność a dobór seksualny

2.4. Kreatywność a inteligencja

3. Związek między psychopatologią a kreatywnością

4. Kreatywność a choroba afektywna dwubiegunowa

4.1. Powiązanie odmian kreatywności ze skłonnością do choroby afektywnej dwubiegunowej

4.2. Zależność przebiegu choroby afektywnej dwubiegunowej i procesu kreatywnego tworzenia

4.3. Kreatywność a stymulacja dopaminergiczna w chorobie afektywnej dwubiegunowej

5. Podsumowanie

\section{Kreatywność: geneza pojęcia i jej definicja}

W odpowiedzi na konieczność dostosowywania się do zmiennych warunków, tak przyrodniczych, jak i społecznych, doszło do nadzwyczajnego rozwoju ludzkiego układu nerwowego. Dlaczego jednak w takiej skali do procesu tego doszło właśnie u przedstawicieli naszego gatunku? W mitologii greckiej ludzkość otrzymała ogień w darze od Prometeusza. (J. Parandowski, 1992) [5] Był to litościwy gest boga, pragnącego dać człowiekowi możliwość ogrzania się i ochrony. W rzeczywistości, człowiek, obserwując procesy prowadzące do samoistnego pojawienia się ognia i mając do dyspozycji proste narzędzia, ostatecznie sam posiadł umiejętność jego rozpalania. Potężna przewaga, jaką dzięki temu zyskał, wynika z nikłej u innych gatunków, a wyjątkowo ożywionej u człowieka kreatywności. Nie dziwi więc fakt, że słowo kreatywność wywodzi się od pojęcia kreacji, (od łacińskiego "creatio"- tworzenie), która w starożytności funkcjonowała w ludzkiej świadomości jako wpływ boskiej ingerencji [6]. Jak opisuje Stein (1953): „Myślenie kreatywne rodzi się z połączenia na nowo istniejących już materiałów albo wiedzy, które po zsumowaniu zawierają elementy zupełnie nowe” [7]. Według Runco (2012) „Kreatywność wymaga spełnienia dwóch kryteriów - oryginalności/nowości, oraz szeroko rozumianej skuteczności, efektywności wytwarzanych w kreatywnym procesie twórczym produktów" [8]. Również Rybakowski (2006) za definicję kreatywności uważa: „Zdolność do tworzenia nowych, społecznie użytecznych lub wpływowych idei” [9]. Człowiek bez trudu dostosowuje się do warunków, w których żyje, podporządkowując sobie dane mu narzędzia w innowacyjny sposób. Dlaczego jednak to właśnie gatunek ludzki do takiego stopnia rozwinął tę cechę?

\section{2. Źródła kreatywności}

Aby uznać pracę za kreatywną, wymagane jest, by jej rezultat był nie tylko oryginalny, ale także w pewnym stopniu społecznie użyteczny [8]. Użyteczność wskazuje, że nowopowstałe idee czy produkty nie są dziełem przypadku. To dowodzi z kolei, że kreatywność związana jest z pewnymi wyższymi procesami umysłowymi: „Dając w ręce szympansa pędzel możemy spodziewać się po pewnym czasie, że dojdzie do namalowania przez niego nowego, wcześniej niespotykanego obrazu. Nie będzie jednak on nigdy dziełem kreatywnym" [8]. Poniżej zaprezentowane zostaną teorie wiążące rozkwit kreatywności u człowieka ze szczególną budową neurochemiczną naszego układu nerwowego. Następnie zostanie zwrócona uwaga na powiązania rozwoju kreatywności z doborem naturalnym, a także na stosunek poziomu inteligencji do kreatywności.

\subsection{Neurobiologiczne podłoże kreatywności}

Badania pozwalające na obrazowanie pracy mózgu przyczyniły się do rozwoju wiedzy na temat neurobiologicznego podłoża kreatywności. Jak się okazuje, nie szczególna dominacja którejkolwiek z półkul, ale ścisła współpraca między nimi i układem mezolimbicznym umożliwia jej wybitny rozwój (Mayseless i wsp., 2015) [10]. Rybakowski (2006) uważa, że równie ważne w procesie two- 
rzenia jest formułowanie nowych idei, za co odpowiedzialne są głównie płaty czołowe i skroniowe, jak i tzw. popęd twórczy. Jest on zależny od pracy mezolimbicznego szlaku dopaminergicznego. Układ dopaminergiczny odpowiada za zwiększenie motywacji do podjęcia procesu twórczego. Zwiększa też wrażliwość na docierające z zewnątrz bodźce. To wzmożone działanie dopaminy tłumaczy niższe utajone hamowanie u osób utalentowanych artystycznie w porównaniu do osób przeciętnych [9].

\subsection{Kreatywność a dobór naturalny}

Wyjaśnienie neurochemicznych czynności mózgu odpowiedzialnych za proces kreatywnego myślenia nie tłumaczy jednak wybitnej u ludzi powszechności tej cechy ani jej zasięgu.

Szacuje się, że około 150 tysięcy lat temu nasi przodkowie wykształcili wszelkie niezbędne cechy anatomiczne pozwalające im na rozwój kreatywności [11]. Prace archeologiczne sugerują jednak, że prawdziwy postęp, jeśli chodzi o tę cechę, nastąpił zdecydowanie później, około 30-40 tysięcy lat temu. Prawdopodobnie ta luka czasowa była okresem naturalnej selekcji. Obdarzeni kreatywnością ludzie mieli większe szanse na dostosowanie się do zmiennych warunków przyrody poprzez opracowywanie odpowiednich metod pracy i coraz bardziej złożonych narzędzi [11].

\subsection{Kreatywność a dobór seksualny}

Sam twórca teorii ewolucji, Karol Darwin, upatrywał wybitnego rozwoju kreatywności u naszego gatunku w doborze seksualnym [12]. Badania Millera i Hasselton (2002) pokazują, że kobiety w fazie płodnej cyklu menstruacyjnego są bardziej skłonne do wejścia w relację z partnerem o niskim statusie ekonomicznym, ale obdarzonym talentem artystycznym, niż z partnerem bogatym, ale pozbawionym podobnych zdolności [13]. Z prac Bussa i wsp. wynika, że poczucie humoru, które także ma związek z kreatywnością, jest silnym atutem w doborze ewentualnego partnera [14]. Czy zatem niesamowita płodność twórcza artystów takich jak Schuman, Goethe czy Czajkowski byłaby efektem ubocznym dążenia naszego gatunku do niesamowitej wręcz ekspansji i rozwoju? A może staraniem poszczególnych osobników do zapewnienia ciągłości swego rodu?

\subsection{Kreatywność a inteligencja}

Z pewnością wysoko rozwinięta inteligencja nie jest warunkiem niezbędnym do ujawnienia się talentu artystycznego. Świadczą o tym wyjątkowe zdolności osób nazywanych sawantami. Wielu spośród tych niezwykłych ludzi, często o ilorazie inteligencji nie przekraczającym 40 pkt., wykazuje ponadprzeciętny talent artystyczny, głównie muzyczny i plastyczny [15]. Przykładem jest historia Lesliego Lemke, który mimo ilorazu inteligencji poniżej 58 punktów był w stanie wykonywać ze słuchu utwory Czajkowskiego (Treffert, 1989) [16] Badania nad sawantami dowodzą wyraźnej zależności między silnym rozwojem półkuli prawej względem lewej (na przykład w wyniku ubytków lub uszkodzeń w obrębie lewej półkuli) a ujawnianiem się ponadprzeciętnych zdolności artystycznych (T. L. Brink, 1980). [17,18] Osoby kreatywne nie muszą wykazywać ponadprzeciętnych zdolności w nauce, jednakże czy możliwe jest, by wyjątkowo kreatywne twórczo mogły być osoby upośledzone intelektualnie? Czy idealne wykonanie sonaty lub doskonale odwzorowana kopia dzieła sztuki świadczą o innowacyjności i oryginalności myślenia? Subtelna granica między mistrzowskim odtwarzaniem a tworzeniem, wymagającym kreatywności musi być więc wyraźnie podkreślona. Z badań Barrona (1981) wynika, iż wprawdzie wysoki poziom inteligencji nie jest równoznaczny z występowaniem kreatywności, jest on jednak warunkiem niezbędnym do jego rozwoju [19].

\section{Związek między psychopatologią a kreatywnością.}

Opierając się na analizie życiorysów wielu sławnych ludzi- związek między kreatywnością a skłonnością do choroby psychicznej, wydaje się być bliski i oczywisty. Już najsłynniejszy starożytny filozof grecki Arystoteles głosił, iż „nie ma geniuszu bez szczypty szaleństwa” Jak mawiał słynny poeta brytyjski lord Byron: “ My artyści wszyscy jesteśmy szaleni. Niektórzy obdarzeni wesołością inni melancholią, ale każdy mniej lub bardziej pomylony": "We of the craft are all crazy. Some are affected by gaiety, others by melancholy, but all are more or less touched." (A. Sussman, 2007) [20]. Jak na ironię, zdaje się wielce prawdopodobne, że sam Byron cierpiał na chorobę afektywną dwubiegunową. Co więcej, nie były odosobnione przypadki choroby psychicznej w jego rodzinie (Ahmed Hankir, 2011) [21]. Prowadzone do tej pory badania pozwoliły potwierdzić istnienie korelacji między poziomem kreatywności a poszczególnymi zaburzeniami psychicznymi. Andreasen [4] dowodzi, że u krewnych I stopnia znanych pisarzy częstość występowania chorób psychicznych jak i poziom kreatywności jest podwyższony. Jamison (1989) w swojej pracy udowadnia, że 38\% badanych przez niej brytyjskich pisarzy i artystów wykazuje zaburzenia afektywne [22] Ludwig (1994) w badaniach nad pisarkami wskazuje na bezpośredni związek między kreatywnością a występowaniem objawów psychopatologii [23]. Prace te zachęciły też do stawiania kolejnych pytań m.in. czy konkretne objawy psychopatologiczne wpływają na zwiększenie lub zmniejszenie poziomu kreatywności? Czy poszczególne etapy przebiegu choroby zbiegają się ze zmniejszeniem lub spadkiem kreatywności u chorych? (Gharidian i wsp. 2001) [24] 


\section{Kreatywność a choroba afektywna dwubiegunowa}

Wyniki dotychczas przeprowadzonych badań wskazują, iż związek między objawami psychopatologicznymi a poziomem kreatywności jest najsilniej uwidoczniony właśnie w chorobie dwubiegunowej [25]. Powiązanie choroby afektywnej dwubiegunowej z kreatywnością wykazują zarówno szczegółowe analizy biografii wybitnych artystów, jak i randomizowane badania kliniczne dotyczące kreatywności wśród osób ze zdiagnozowaną chorobą dwubiegunową. Akiskal i Akiskal (1988) w swojej pracy badawczej obejmującej 750 pacjentów wykazują, że pacjenci z typem II i III choroby dwubiegunowej cechują się zwiększoną kreatywnością artystyczną w stosunku do grupy kontrolnej [26]. Badania Richardsa i wsp. (1988) wykazują, że artyści z chorobą afektywną dwubiegunową wyróżniają się dłuższą karierą artystyczną w porównaniu z artystami bez zdiagnozowanych zaburzeń afektywnych. Zarówno dorośli z cyklotymią, jak i krewni pierwszego stopnia osób z chorobą afektywną dwubiegunową (ale nie sami pacjenci) posiadają znacząco wyższe wyniki kreatywności artystycznej w porównaniu z grupą kontrolną [27].

\subsection{Powiązanie odmian kreatywności ze skłonnością do choroby afektywnej dwubiegunowej.}

Co ciekawe, badania Sass'a (2001) wskazują na istnienie istotnej zależności między występowaniem choroby dwubiegunowej a kreatywnością głównie wśród artystów [28]. Mniej wyraźne związki zauważalne są u osób kreatywnych np. w dziedzinach naukowych (Simonton, 2001) [29]. Artyści bowiem charakteryzują się odmiennym typem kreatywności niż np. inżynierowie czy matematycy [30]. Zauważa się, że w dużej mierze, oprócz kreatywności, artyści cechują się nonkonformizmem, złożonością zainteresowań. Duże znaczenie przypisują intuicji i niezależności [31]. Zagadnienie to w swoich pracach rozwija Sass (2001), łącząc korelację między chorobą afektywną dwubiegunową i kreatywnością u artystów z pewnymi konkretnymi predyspozycjami osobowościowymi takimi jak uczuciowość, przykładanie dużego znaczenia panującej hierarchii społecznej („wyższość odczuwana w manii, poczucie odrzucenia w depresji”) [28]. Czy można więc traktować chorobę afektywną dwubiegunową jako efekt uboczny niezwykłej wrażliwości motywującej artystów do ich twórczej pracy? Nancy Andreasen (2008) zwraca uwagę, że nadmierna wrażliwość na otaczające bodźce może także prowadzić artystów do poszukiwania rozwiązań, mających na celu złagodzenie silnych wahań nastrojów [32]. Wyjaśniać to może skłonność artystów do nadużywania alkoholu (Prisciandaro i wsp., 2011) [33], jak i nieprzypadkowe często podejmowane próby samobójcze (Ludwig, 1997) [34].

\subsection{Zależność przebiegu choroby afektywnej dwubie- gunowej i procesu kreatywnego tworzenia}

Akiskal i Akiskal zauważają także, iż wysoka kreatywność dotyczy pacjentów charakteryzujących się głównie łagodnym przebiegiem choroby [26]. Praca Gharidian i wsp., również zwraca uwagę na powiązanie wysokich wartości kreatywności wyłącznie z łagodnymi i umiarkowanymi objawami psychopatologicznymi [24]. Najwyższa płodność artystyczna brytyjskiej pisarki Virginii Woolf (1882-1941), cierpiącej na chorobę afektywną dwubiegunową, nakładała się w czasie na epizody choroby charakteryzujące się łagodnymi wahaniami nastroju. Ciężkie epizody były z kolei etapem wyraźnego spadku twórczości. Można domniemywać jedynie, że doświadczenia z owych okresów były inspiracją do tworzenia kolejnych dzieł. Zmagania z nawrotem choroby w $1941 \mathrm{r}$. doprowadziły wybitną artystkę do samobójstwa [31]. Prace badawcze Andreasen (2008) wiążą okres wychodzenia z depresji z największą pomysłowością u artystów cierpiących na chorobę afektywną dwubiegunową. Pomysłowość ta, wynikająca, jak sądzą badacze, z głębokich przeżyć tego okresu choroby, przekłada się na wybuch twórczości w fazie hipomaniakalnej [32]. Większa twórczość w hipomanii niż w manii została potwierdzona wynikami pracy Akiskal i Akiskal (1988). Zaobserwowano, że poziom kreatywności w różnych epizodach choroby rozkładał się następująco od najwyższego do najniższego: hipomania, mania, hipodepresja, depresja [26]

\subsection{Kreatywność a stymulacja dopaminergiczna w chorobie afektywnej dwubiegunowej}

Wysokie wskaźniki kreatywności wiąże się ze zwiększonym przekaźnictwem w zakresie układu dopaminergicznego Soeiro-de-Souza (2011) [35]. Wyniki te potwierdza analiza biografii słynnego kompozytora, Roberta Schumanna (1810-1856). Epizody głębokiej manii okupił on uszkodzeniem stawów prawej ręki, związanym ze zbyt intensywną grą na pianinie. Stany hipomaniakalne łączyły się u niego natomiast z okresami bezsenności oraz halucynacjami słuchowymi o charakterze przeżyć muzycznych. Po kilku dniach nieustającej pracy twórczej, Schumann popadał powoli w stan depresji. Kreatywność opuszczała go, ustępując miejsca zmęczeniu, myślom samobójczym, halucynacjom wzrokowym i poczuciu beznadziejności. Ostatecznie, w 1854 roku, po nieudanej próbie samobójczej, Schumann został umieszczony w szpitalu psychiatrycznym, zmarł rok później (Kusz W., 2010), (Ostwald P., 1985) [36,37] Do bardzo podobnych wniosków dochodzą badacze interpretujący biografię niemieckiego pisarza - Johana Wolfganga Goethego. Drobiazgowa analiza pozwoliła na stwierdzenie, że pisarz ten cierpiał na chorobę afektywną dwubiegunową typu II R.M. Holm-Hadulla et al. (2010). Jak się okazuje, epizody depresji dały artyście natchnienie i motywację do stworzenia chociażby słynnego „Fausta”. Stany hipomaniakalne pozwalały zaś przezwyciężyć poczucie zwątpienia, wpro- 
wadzały w samozadowolenie, a tym samym umożliwiły przekształcenie myślowych koncepcji w gotowe dzieło [38].

\section{Podsumowanie}

Zmagania z chorobą psychiczną wybitnych artystów takich jak Sylvia Plath, Ernest Hemingway, Vincent van Gogh czy Emily Dickinson zmuszają do zadania pytania: czy geniusz ociera się o szaleństwo? Banalnym i krzywdzącym byłoby stwierdzenie, że szaleństwo rozumiane jako występowanie objawów psychotycznych równoznaczne jest z geniuszem. Jak twierdzą analitycy biografii Goethego, pisarz przez całe życie uczył się jak zaakceptować i złagodzić swoje zaburzenia nastroju. Artysta za każdym razem na nowo przezwyciężał stany niepokoju, poczucie izolacji i melancholii. Zaprowadziło go to jednak do mistrzostwa w dziedzinie literackiej [38]. Ogromne cierpienie, wiążące się często z objawami choroby psychicznej, będące bez wątpienia udziałem najsłynniejszych artystów, można więc interpretować jako efekt uboczny wielkiej kreatywności lub jako element ciężkiej drogi przez którą każdy artysta zmuszony jest kroczyć samodzielnie.

\section{Conflict of interest}

The authors have declared no conflict of interest.

\section{References:}

1. Darwin C. The expression of emotions in man and animals. London, Friedman, 1979.

2. Hamilton WD. Narrow roads of gene land. W: Dawkin R, red. The collected papers of W. D. Hamilton. Oxford, New York, W. H. Freeman/Spektrum; 1996.

3. Rybakowski F, Rybakowski J. Ewolucyjne koncepcje zaburzeń afektywnych. Psychiatria Polska.2006; XL; 3:401-413.

2. Andreasen NC. Am J Psychiatry. 1987 Oct;144(10):1288-92.

3. Parandowski J. Mitologia. Wierzenia i podania Greków i Rzymian. Kraków, Dom Książki, 1992.

4. Batey M, Furnham A. Genetic, Social, and General Psychology Monographs.2006; 132(4): 355-429.

5. Stein, M. I. Creativity and culture. Journal of Psychology.1953; 36: 31-322.

6. Runco M., Jaeger J. The Standard Definition of Creativity. Creativity Research Journal.2012; 24(1):92-96.

7. Rybakowski J, Klonowska P, Patrzała A, Jaracz J. Psychopatologia a kreatywność. Psyciatria Polska.2006;(XL)6:1033-1049.

8. Mayseless N, Shamay-Tsoory S.G. Enhancing verbal creativity: Modulating creativity by altering the balance between right and left inferior frontal gyrus with tDCS.Neuroscience. 2015;291:167-176.

9. Carruthers P. Human Creativity: Its Cognitive Basis, its Evolution, and its Connections with Childhood Pretence. Brithish journal for the philosophy of science.2002; 53(2): 225-249.

10. Darwin C. The Descent of Man and Selection in Relation to Sex. London, J Murray; 1871.

11. Haselton M.G, Miller G.F. Women's Fertility across the Cycle Increases the Short-Term Attractiveness of Creative Intelligence.
Human Nature: An Interdisciplinary Biosocial Perspective [10456767]2006;17(1):50 -73.

12. Buss D. The Evolution of Desire: Strategies of Human Mating. New York, BasicBooks; 2003.

13. Treffert D. The savant syndrome: an extraordinary condition. A synopsis: past, present, future. Philosophical transactions - Royal Society. Biological sciences [0962-8436] 2009;364 (1522): 1351-7.

14. Treffert D. An unlikely virtuoso: Leslie Lemke and the story of savant syndrome.Sciences [0036-861X]. 1989;29(1): 28.

15. Brink, T. L. Idiot savant with unusual mechanical ability: An organic explanation. American Journal of Psychiatry, 1980; 137: 250-251.

16. Wallace G. Neuropsychological Studies of Savant Skills: Can They Inform the Neuroscience of Giftedness? Roeper Review [02783193]. 2008; 30(4): 229 -246.

17. Barron F.Creativity, Intelligence, and Personality. Annual Review of Psychology. 1981; 32(1):439 -476.

18. Sussman A. Mental Illness and Creativity: A Neurological View of the "Tortured Artist". Stanford Journal of Neuroscience. 2007; 1(1):21-24.

19. Hankir A. Rewiev: Bilolar Disorders and Poetic Genius. Psychiatria Danubina, 2011;23(1): 62-68.

20. Jamison KR. Mood disorders and patterns of creativity in British writers and artists. Psychiatry 1989; 52: 125-34.

21. Ludwig AM. Mental illness and creative activity in female writers. Am J Psychiatry 1994; 151: 1650-6.

22. Ghadirian A-M, Gregoire P, Kosmidis H. Creativity and the Evolution of Psychopathologies. Creativity Research Journal. 20002001; 13(2): 145-148.

23. Runco M. Creativity. Annu. Rev. Psychol. 2004; 55:657-87.

24. Akiskal H.S, Akiskal K. Re-assessing the prevalence of bipolar disorders: clinical significance and artistic creativity. Psychiatry Psychobiol. 3 European Psychiatry. 1988.

25. Richards, Ruth, Kinney, Dennis K, Lunde, Inge, Benet, Maria, Merzel, Ann P.C. Creativity in manic-depressives, cyclothymes, their normal relatives, and control subjects. J. Abnorm. Psychol. 1988; 97 (3): 281-288.

26. Sass L.A. Schizophrenia, Modernism, and the "Creative Imagination": On Creativity and Psychopathology. Creativity research journal. 2001; 13(1):55 -74.

27. Simonton D.K. Creativity: Cognitive, personal, developmental, and social aspects. American Psychologist, 2001; 55(1): 151-158.

28. Andreasen N. Creativity in art and science: are there two cultures? Dialogues in clinical neuroscience. 2012 14(1):49-54.

29. Rybakowski J. Oblicza choroby maniakalno-depresyjnej. Poznań, Termedia Wydawnictwa Medyczne; 2009.

30. Andreasen N. The relationship between creativity and mood disorders. Dialogues in clinical neuroscience. 2008; 10(2)2: 251 -255.

31. Prisciandaro J.Predictors of clinical trial dropout in individuals with co-occurring bipolar disorder and alcohol dependence. Drug and alcohol dependence. 2011; 118(2-3):493 -496.

32. Ludwig A. Creative achievement and psychopatology. Comparison among professions. In: Runco, M. Richards, R. Emintent creativity, everyday creativity, and health. Ablex, Greenwich. 1997.

33. Soeiro-de-Souza M.G. Soares D, Post R, Moreno R.A. Creativity and executive function across manic, mixed and depressive episodes in bipolar I disorder. Journal of Affective Disorders. 2011; 135(1): 292-297.

34. Kusz W. Biografia Roberta Szumana widziana oczami psychiatry. Current Problems Of Psychiatry. 2010; 11(4): 313-322.

35. Ostwald P, Schumann: The Inner Voices of a Musical Genius. Boston, Northeastern University Press. 1985.

36. Holm-Hadulla R.M., Goethe's study crisis, depression and his selftreatment strategies. Psychotherapeut. 2009; 54: 370-374. 


\section{Correspondence address}

Olga Nowacka

Studenckie Koło Naukowe przy Zakładzie Neuropsychiatrii Klinicznej Katedry Psychiatrii Uniwersytetu Medycznego w Lublinie e-mail: olgajulianowacka@gmail.com

Otrzymano: 01.12.2016

Zrecenzowano: 12.02.2017, 09.02.2017, 22.02.2017

Przyjęto do druku: 16.03.2017 